This paper is a preprint of the paper that will appear in the Business Strategy and the Environment journal

(2017) Published in Business strategy and environment, vol 26, no 4, pp. 550-568, 2017, which should be cited to refer to this work. DOI : 10.1002/bse.1946

\title{
Sustainability in the Banking Industry: A Strategic Multi-criteria Analysis
}

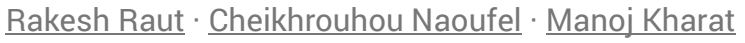 \\ Geneva School of Business Administration \\ University of Applied Sciences Western Switzerland HES//SO \\ 1227 Geneva
}

\begin{abstract}
Most of the works related to multi-criteria decision-making in the service industry have a focus on common issues such as improving service quality or lead time and do not give enough importance to sustainability. The purpose of this paper is to develop an effective and integrated multi criteria decision making model for the evaluation of the sustainability practices in the banking services. Due to its dependence upon multiple criteria, the evaluation process proposed is based on a multi-stage, fuzzy multi-criteria decision-making model that integrates balanced scorecard, Fuzzy-Analytic Hierarchy Process and Fuzzy-TOPSIS (Technique for Order of Preference by Similarity to Ideal Solution). The approach aims to evaluate sustainability from the following four perspectives: financial stability, customer relationship management, internal business process, and environment-friendly management system. A real implementation dealing with the six largest commercial banks in India is discussed. The analysis of the results highlights the critical aspects of the evaluation criteria and the issues in improving sustainable banking performances. Regarding the sustainability issues, it is shown that the environment-friendly management system takes a backseat compared to the other criteria. Furthermore, the results show that there is a misunderstanding of the role that corporate social responsibility plays with respect to environmental issues.
\end{abstract}

Keywords: Sustainability, Banking, Performance Evaluation, Multi-criteria Decision-making, Balance Scorecard, Fuzzy Logic, AHP, TOPSIS.

\section{Introduction}


This paper is a preprint of the paper that will appear in the Business Strategy and the Environment journal (2017)

The impact of sustainability on competitiveness and corporate economic success has been strongly debated for many decades (Bragdon and Merlin, 1972; Porter and van der Linde, 1995; Palmer et al., 1995; Lankoski, 2000). So far, sustainability has been mainly addressed in manufacturing and supply chain activities. With increasing environmental concern and consumers' demand for environmentally-friendly products or services, the firms have introduced a variety of green innovative initiatives and practices, such as green products and service design (Tseng et al., 2013 a, b). The focus is put, in particular, on green technologies and green management (Manley et al., 2008). The World Resources Institute (WRI, 2009) reports that at least $80 \%$ of carbon emissions are produced in the total supply chain with a direct influence on organizational activities and business practices (Lee, 2012). Considering the enormous environmental challenges in today's scenario - such as a number of environmental laws and regulations, demanding organizational stakeholders' pressures and gaining competitive advantage - organizations and businesses are attempting to balance social, economic, and environmental performance through sustainable development principles (Boiral, 2006; Lee et al., 2009; Jabbour and Jabbour, 2009; Shen et al., 2012). Many countries and organizations started to enforce environmental legislations and regulations for controlling the use of products, processes and wastes that may be detrimental to the environment (Lee et al., 2009) as a part of quality and sustainability management (Zhang, 2004; Lee et al., 2009; Shen et al., 2012). Gunasekaran and Spalanzani (2012) state that companies have been under increasing pressure to seriously think about their sustainable business practices, both in manufacturing and services. A few years ago, there was a paradigm shift in thinking with regard to improving the social and environmental performances of organizations (Hart and Milstein, 2003; Govindan et al., 2012). However, the service industry has received much less attention than the manufacturing industry. In particular, the banking sector plays an important role in a nation's economy and significantly contributes toward sustainable development.

In comparison with other sectors, banks have wider role, more visibility in society and a higher product involvement. While other sectors are reactive to sustainability due to external stakeholder pressure (Sallyanne Decker, 2004), banks are getting proactively engaged in sustainable activities. Consequently, banks extensively engage in sustainability and Corporate Social Responsibility (CSR) activities as part of their strategy to produce value and improve their public image (McDonald and Lai, 2011) and the customer related outcomes (Bhattachraya and Sen, 2004). Moreover, as the reputation of financial institutions relies on their socially responsible activities (Poolthong and Mandhachitara, 2009), banking institutions tend to have a high rank on the international CSR investment ranking index (Perez et al., 2013). 
This paper is a preprint of the paper that will appear in the Business Strategy and the Environment journal (2017)

Proper performance measurement/evaluation is an important issue for banking industries, as this can affect the overall performance, productivity and profit of a banking system. For proper and effective evaluation, the decision-maker may need a large amount of data to be analyzed and many factors to be considered (Ayag`and Özdemir, 2006; Dagdeviren et al., 2009). Moreover, to outperform competing bank institutions, more emphasis on internal operational performance is required. Indeed, there is a need for the development of an effective way to conduct performance evaluations that can measure overall organizational performance and link it to the corporate goals. This holistic evaluation model of banking performance is a key factor for the evaluation of the bank sustainability features. Despite the increasing interest of sustainability in this sector, there are no studies dealing with the evaluation of sustainability in the banking sector with a multidimensional perspective in a developing economy.

The objective of this paper is to present an integrated multi-criteria decision model for the evaluation of sustainability from the economic, social and environmental perspectives rather than focusing only on a single criterion.

The rest of this paper is organized as follows. In Section 2, a detailed review of literature is presented to identify the different criteria considered. In section 3, the research methodology is presented and the multi-criteria evaluation method is developed and explained. In section 4 , an application of the approach in the Indian Banking Sector is presented. Finally, conclusions and suggestions for future studies are provided in section 5.

\section{Research background}

One of the criteria in sustainability is the environment management. Sustainability and environmental responsibility has become a priority in corporate sector (Lozano, 2012; Lozano et al., 2014). Environment management is the integration of operations, economics, and human resource policies. Jabbour and Jabbour (2009) stated that "Environmental management is a consistent set of administrative and operational policies and practices that considers the protection of the environment through the mitigation of environmental impacts and damage resulting from planning, implementation, operation, expansion, reallocation or deactivation of ventures or activities, including all of the product's life cycle phases".

Wu et al. (2009) proposed a Fuzzy Multiple Criteria Decision Making (FMCDM) approach for the evaluation of banking performance. They developed a comparative model using different 
This paper is a preprint of the paper that will appear in the Business Strategy and the Environment journal (2017)

MCDM techniques, such as balanced scorecard (BSC), Fuzzy-Analytic Hierarchy Process (FAHP), Technique for Order of Preference by Similarity to Ideal Solution (TOPSIS), and Multi-criteria Optimization and Compromise Solution (VIKOR). Using expert questionnaires, 23 criteria were selected. Furthermore, the relative weights of the chosen evaluation indexes are calculated using FAHP. Three MCDM analytical tools of Simple Additive Weighting (SAW), TOPSIS, and VIKOR were adopted to rank the banking performances of three selected banks. The results suggest that, for a more effective performance, it is crucial to improve the banking relationship by matching the needs of the clients to the delivery process of client services (Nist, 1996 cited by $\mathrm{Wu}, 2012)$. BSC has been utilized as a framework to develop the evaluation indicators for banking performance (Davis and Albright, 2004; Kim and Davidson, 2004; Wu et al., 2009). Wu (2012) proposed a structural evaluation methodology to link the key performance indicators (KPIs) in a strategic map of BSC for banking institutions. With respect to the four BSC perspectives (finance, customer, internal business process, and learning and growth), the most important evaluation indicators of banking performance were synthesized from the relevant literature, and screened by a committee of experts. Then, Decision Making Trial and Evaluation Laboratory (DEMATEL) method was applied to determine the causal relationships between the KPIs and identify the critical central and influential factors. Seçme et al. (2009) applied a FMCDM model to evaluate the performances of some banks. In their implementation FAHP and TOPSIS were integrated to evaluate the five largest commercial banks of Turkey in terms of several financial and non- financial indicators. Devlin and Gerrard (2005) addressed the relative importance of various evaluation criteria in the selection of a banking institution by applying statistical analysis. They provided an analysis of customer choice criteria and made an itemized comparison of the relative importance of choice criteria, which impact the choice of main and secondary banking institutions. Kuo and Chen (2010) examined the four perspectives of the BSC consisting of financial, customer, internal process, and learning and growth perspectives. They applied Fuzzy Delphi Method to construct key performance appraisal indicators for mobility of the service industries. The research findings showed that cost control, profit growth, and sales growth are the top three indicators in the financial perspective, while service/product quality, customer satisfaction, and service timing are the three major indicators in the customer perspective. In the internal process perspective, information delivery, standard operation procedure, and interactions between staffs and clients are the most valued criteria. In the learning and growth perspective, corporate image, competitiveness, and employee satisfaction are the most emphasized criteria. Leung et al. (2006) showed that the Analytic Hierarchy Process (AHP) and the Analytic Network Process (ANP) can be tailor-made for specific situations and can be used to overcome some of the traditional problems of BSC implementation, such as the 
This paper is a preprint of the paper that will appear in the Business Strategy and the Environment journal (2017)

dependency relationship between measures and the use of subjective versus objective measures. Establishing strategy maps with clearly causal/ logical links leads to the establishment of strategic pathways throughout the organization (Evans, 2007). Möller and Schaltegger (2005) proposed a Sustainable Balanced Scorecard (SBSC) framework for eco-efficiency analysis, which specified subsequent information management, data collection, and modeling steps. They embedded eco-efficiency indicators into an SBSC strategy map to estimate and control the appropriate key performance indicators of two major aspects of sustainability, namely, environmental and economic issues. Yongvanich and Guthrie (2006) developed "extended performance reporting framework," which included the BSC, social and environmental reporting, and "intellectual capital". To integrate measures in the SBSC, Hubbard (2009) developed a conceptual model for measuring organizational performance that responds to the increasing pressures for wide and inclusive, but simple measures of organizational performance. It is based on the well-established stakeholder-theory-based BSC. It widens the stakeholder base by adding factors specifically designed to capture a firm's social and environmental performance to create a SBSC. Furthermore, it is simple as it develops an Organizational Sustainable Performance Index (OSPI), a single indicator that was invaluable for communicating organizational performance simply to non-expert, but nevertheless critical stakeholders. Hsu et al. (2011) proposed a SBSC framework to measure the sustainable performance of the semiconductor industry. Based on the principle of four perspectives of BSC, of which two were changed from the financial and customer perspectives to sustainability and stakeholder perspectives to deal with the insufficiently addressed issue of corporate social responsibility. 25 measures of sustainable performance were identified through expert questionnaires and the fuzzy Delphi method (FDM). The relative weights of the selected measures were determined using ANP.

Regarding Bank financial performances, the literature reveals its richness in the development of approaches for the evaluation of bank performances (Anderson et al., 1976; Boyd et al., 1994; Elliot et al., 1996; Chia and Hoon, 2000; Devlin and Gerrard, 2005; Kosmidou et al., 2006). Several studies on bank performance measurement examined, the economies of scale and scope employing statistical methods such as correlation analysis (Arshadi and Lawrence, 1987), translog cost function (Gilligann et al., 1984; Murray and White, 1983; Molyneux et al., 1996), loglinear models, or tools like Data Envelopment Analysis (DEA), etc. (Giokas, 1991; Athanassopoulos and Giokas, 2000; Drake, 2001). Kosmidou et al. (2006) investigated the effectiveness and performance of UK based banks. Based on their assets, banks were 
This paper is a preprint of the paper that will appear in the Business Strategy and the Environment journal (2017)

distinguished into small and large ones, and a classification of UK banks in a multivariate environment for the period 1998-2002 was done. The PAIRCLAS multi criteria methodology was employed to investigate the performance of banks over multiple criteria, such as asset quality, capital adequacy, liquidity and efficiency/profitability. A comparison with discriminant analysis (DA) and logistic regression (LR) facilitated the investigation of the relative performance of PAIRCLAS against them. The results of the study determined the key factors that specified the classification of a bank as small or large. Kaya (2001) carried out the performance analysis of Turkish banking sector through CAMELS evaluation system, which facilitated the measurement of financial success of banks. Demir and Astarcioglu (2007) analyzed the Turkish commercial banks' performance with DEA by taking into consideration banks' total commercials, the interest income and expenses, the credits granted and the noninterest income and expenses. The impact of ownership on bank performance was examined employing DEA by Isik et al. (2003), Denizer et al. (2000), and Lin and Zhang (2009). Beccalli (2007) examined the relation between bank performances and the investments in informatics. The author analyzed the data between 1995-2000 for 737 banks operating within the European Union, considering financial rate, cost, profitability and productivity criteria. Ravi et al. (2008) developed models using neural networks and statistical techniques for the estimation of banks' financial performances by using financial variables. Albayrak and Erensal (2005) analyzed the financial and non-financial performance criteria for the performance evaluation of Turkish banks using FAHP. Previous research findings rather confirm that, the social dimension needs much better integration with the economic and environmental ones. Collier (1995) employed structural equation models to analyze the process performance of banks using criteria such as process quality errors, employee turnover rate, labor productivity, on-time delivery, and unit cost. The related literature highlights that the selection criteria that customers use to select and evaluate the banks include price, speed, access, customer service, location, image and reputation, modern facilities, interest rates, opening hours, incentive offered, product range, and service charge policy (Anderson et al., 1976; Martenson, 1985; Boyd et al., 1994; Elliot et al., 1996; Chia and Hoon, 2000; Devlin, 2002; Devlin and Gerrard, 2005; Wu et al., 2009). However, this is the perception of only one kind of stakeholders.

A large number of studies on performance measurement systems in the service industry are reported in the literature (Bititici and Nudurupati, 2002; Chan and Qi, 2003a, 2003b; Chan et al., 2006; Wu et al., 2009; Awasthi et al., 2011).-Meyer and Markiewicz (1997) grouped the measures related to the critical success factors of banking performance into eight categories: (1) profitability, (2) efficiency and productivity, (3) human resource management, (4) risk 
This paper is a preprint of the paper that will appear in the Business Strategy and the Environment journal (2017)

management, (5) sales effectiveness, (6) service quality, (7) capital management, and (8) eompetitive positioning. Fitzgerald et al. (1991) discussed the performance measurement in the service sector based on the premises that there are two basic types of performance measures in any organization, those that relate to results (competitiveness, financial performance), and those that focus on the determinants of the results (quality, flexibility, resource utilization and innovation). This distinction highlights the fact that the results obtained are function of past business performance with regard to specific determinants. According to Wagner and Schaltegger (2004), the performance measures should include: (i) environmental shareholder value perspective (premium price for products, lower costs for processes, lower capital investments for processes, better utilization of equipment, competitive advantage, longer operational life of production equipment and products); (ii) environmental competitiveness (competitive advantage, product image, sales, market share, new market opportunities, corporate image, shareholder satisfaction, management satisfaction, work satisfaction, recruitment and retention, short term and long term profits, cost savings, productivity, and access to bank loans); and (iii) environmental performance (use of water, use of energy, use of non-renewable resources, use of toxic inputs, solid waste, soil contamination, waste water emissions, emissions to air, noise, smell/odor emissions, landscape damage, and risk of severe accidents). Szekely and Knirsch (2005) identified suitable performance measures and metries based on the following elassification criteria: i) Economic metries (net profit earning/income, gross margin, capital investment, R\&D, knowledge, human capital, reputation, brands, networks, partnership; return on investment, employee remuneration, funding for training, taxes, tax breaks, royalties, subsidies, job creation, infrastructure development, technology transfer, and social capitat formation), ii) Environmental metries (human natural resource consumption, waste output, and earbon footprint) and iii) Social metries (human rights, labor/employment issues, supplier relationships, community initiatives and corporate philanthropy).

Several performance measurement systems have been reported in the literature (Bititici and Nudurupati, 2002; Chan and Qi, 2003a, 2003b; Chan et al., 2006; Wu et al., 2009, Önüt et al., 2009, Awasthi et al.,2011). Fitzgerald et al. (1991) discussed performance measurement in the service sector, stating that there are two basic types of performance measures in any organization: those that relate to results (competitiveness, financial performance), and those that focus on the determinants of the results (quality, flexibility, resource utilization and innovation). The appeal of this distinction is that it highlights the fact that the results obtained are a function of past business performance with regard to specific determinants - i.e., results are lagging indicators, whereas determinants are leading indicators. Azzone et al. (1991) developed a framework that identifies the most appropriate measures for organizations to pursue a strategy of 
This paper is a preprint of the paper that will appear in the Business Strategy and the Environment journal (2017)

time-based competition. The BSC breaks through the traditional limitations of finance, examining an organization's performance from the four main perspectives of finance, customer, internal business process, and learning and growth. According to Kaplan and Norton (1992) and Neely et al. (2000), such an approach allows managers to answer four fundamental questions: (1) How do we look at our shareholders (financial perspective)? (2) What must we excel at (internal business perspective)? (3) How do our customers see us (the customer perspective)? (4) How can we continue to improve and create value (innovation and learning perspective)? It emphasizes both aspects of the financial and non-financial, long-term and short-term strategies, and internal and external business measures.

As pointed out by Figge et al. (2002) and Hsu et al. (2011), sustainability management with BSC helps to overcome the shortcomings of conventional approaches in environmental and social management systems by integrating the three pillars of sustainability into a single and overarching strategic management tool. SBSC should include social and environmental issues in the existing BSC (Hubbard, 2009). Yongvanich and Guthrie (2006) considered the BSC as a base for doing this. However, they developed their own 'extended performance reporting framework', which included the BSC, social and environmental reporting and 'intellectual capital'. Therefore, the SBSC may not only help to detect important strategic environmental and/or social objectives of the company, but may also enhance the transparency of value-added potentials emerging from social and/or ecological aspects and prepare the implementation process of the strategy (Bieker and Waxenberger, 2002).

In conclusion, the different studies addressing either the performance evaluation of the banking services or the bank selection problem lack consideration of a holistic approach and sustainability features in the evaluation criteria. Moreover, sustainability is not limited to the long term profitability only, as it is considered in some works, but extends to the triple bottom line principles. The concept of triple bottom line (TBL) developed by Elkington (1997) stresses the distinction between the economic and the social dimensions of sustainability, which have been absorbed by the environmental dimension of sustainability in the litearture. The integration of all three dimensions/criteria (economic, social, and environmental) plays a central role, but is not often addressed in the literature (Seuring and Müller, 2008).

The main contribution of this paper is the development of an integrated multi-criteria decisionmaking technique for sustainability evaluation and ranking in the banking services based on the combination of the TBL concept with BSC. As the assessment procedure done by decision 
This paper is a preprint of the paper that will appear in the Business Strategy and the Environment journal (2017)

makers contains subjectivity, uncertainty and ambiguity, this work uses fuzzy principles to express the decision variables and criteria.

\section{Proposed methodology}

\subsection{Background}

The Balanced Scorecard (BSC) is an extensive and thorough performance evaluation tool to adequately plan and control an organization so it can attain its goals (Pinero, 2002; Davis and Albright, 2004; Lawrie and Cobbold, 2004; Wu et al., 2009). The need of performance measurement systems at different levels of decision-making, either in the industry or service contexts, has been discussed numerous times (Bititici et al., 2002; Sharma and Bhagwat, 2007). BSC is introduced by Kaplan and Norton (1992) as a multi-dimensional performance measurement system that includes financial outcome and short-term as well as non-financial and long-term measures. A key feature of the BSC is its emphasis on linking the performance measures with business unit strategy (Wong-On-Wing et al., 2007). In a study of financial services firms by Ittner et al. (2003), it was found that among those claiming to use a balanced scorecard, $76.9 \%$ placed little or no reliance on their strategically-linked causal business models. Sharma and Bhagwat (2007) reported that many companies are adopting the BSC as the foundation for their strategic management system. Some managers have used it as they align their businesses to new strategies, moving away from cost reduction and towards growth opportunities based on more customized, value-adding products and services (Martinsons et al., 1999). Lee et al. (2008) examined FAHP and BSC for evaluating an IT department in the manufacturing industry in Taiwan. The BSC concept was applied to define the hierarchy with four major perspectives (i.e., financial, customer, internal business process, and green management system), from which performance indicators were selected.

\subsection{Proposed approach for banks ranking}

The problem faced in this paper is the development of a ranking approach for different banks under consideration taking into account sustainability perspective as a concept of performance. Several banks are considered for ranking by multiple decision makers. The criteria are selected according to an integrated multi-criteria approach as illustrated in Figure 1.

A performance analysis is conducted based on the selected evaluation attributes using BSC. Then, a Fuzzy Analytic Hierarchy Process (FAHP) is developed to calculate the relative weights 
This paper is a preprint of the paper that will appear in the Business Strategy and the Environment journal (2017)

of the performance measurement indexes. According to these weights, a Fuzzy TOPSIS (FTOPSIS) technique is developed to obtain the performance ratings of the feasible alternatives in linguistic values parameterized with triangular fuzzy numbers. The approach is suitable for the problem under consideration for the following reasons:

(1) BSC is well adapted to the needs for a multi-dimensional performance measurement system

(2) The computation processes are straightforward

(3) The importance of weights are incorporated into the comparison procedures

(4) In contrast with other methods, it is less computationally demanding (Hwang and Yoon, 1981; Wang and Chang, 2007; Wu et al., 2009; Jolai et al., 2011).

(5) Fuzzy TOPSIS logic is rational and understandable for decision makers

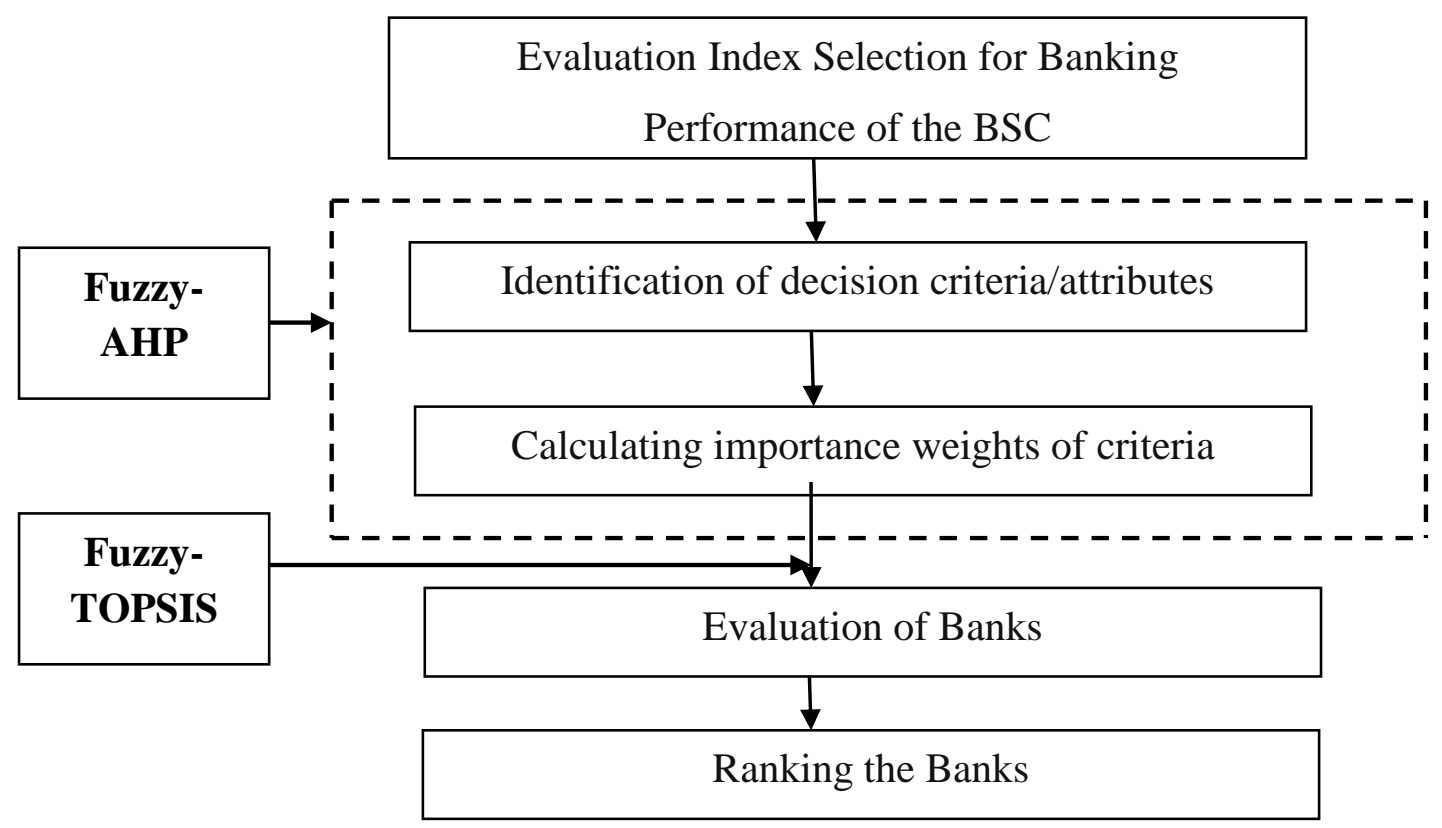

Figure 1: The proposed Framework

The main advantage of FAHP method is the relative ease in handling multiple attributes/criteria (Kahraman et al., 2007). In addition, it provides a systematic tool for calculating weights of criteria through pairwise comparisons instead of directly assigning weights to criteria (Saaty, 1980). The feasible region to include tolerance deviations of the fuzzy ratios, here we define fuzzy consistency as the existence of relative weights within the region and secondly we devise a maximum/minimum set ranking method to derive a crisp ranking from the global fuzzy weights (Leung and Cao, 2000; Jolai et al., 2011). Table 1 depicts the scale used for pairwise comparisons between criteria, where linguistic variables are converted to triangular fuzzy numbers (Kuo et al., 2006; Chiou et al., 2005; Tseng et al., 2009). The triangular fuzzy numbers 
This paper is a preprint of the paper that will appear in the Business Strategy and the Environment journal (2017)

(TFNs) are denoted $M=(l, m, u)$, where $l$ and $u$ are the lower and upper bounds of the definition interval and $m$ is the maximum grade of the membership function as follows

$$
\left\{\begin{array}{l}
\frac{(x-l)}{(m-l)}, l \leq x \leq m \\
\frac{(u-x)}{(u-m)}, m \leq x \leq u \\
0, \text { otherwise }
\end{array}\right.
$$

TFNs are used to represent evaluators' subjective measures to determine the degrees of importance among evaluation criteria and also to assess the performance value of alternatives.

\section{Table 1: Fuzzy Analytic Hierarchy Process Scale (linguistic variables)}

\begin{tabular}{|c|l|}
\hline $1,1,1$ & Equal importance \\
\hline $2 / 3,1,3 / 2$ & Low importance \\
\hline $3 / 2,2,5 / 2$ & High importance \\
\hline $5 / 2,3,7 / 2$ & Very high importance \\
\hline $7 / 2,4,9 / 2$ & Absolute importance \\
\hline
\end{tabular}

Relying on the Chang's (1996) extent analysis, $m$ extent analysis values for each object are considered as TFNs $M_{g^{i}}^{j}(j=1,2, \ldots, m$.$) . The steps of Chang's extent analysis (Chang, 1996,$ Raut et al., 2011) are as follows:

Step 1: The value of fuzzy synthetic extent with respect to the $i^{\text {th }}$ object is defined in Equation (1)

$$
S_{i}=\sum_{j=1}^{m} M_{g^{i}}^{j} \otimes\left[\sum_{i=1}^{n} \sum_{j=1}^{m} M_{g^{i}}^{j}\right]^{-1}
$$

To obtain $\sum_{j=1}^{m} M_{g^{i}}^{j}$, the fuzzy addition operation of m extent analysis values for a particular matrix is performed such as

$$
\sum_{j=1}^{m} M_{g^{i}}^{j}=\left(\sum_{j=1}^{m} l_{j}, \sum_{j=1}^{m} m_{j}, \sum_{j=1}^{m} u_{j}\right)
$$


This paper is a preprint of the paper that will appear in the Business Strategy and the Environment journal (2017)

and the value $\left[\sum_{i=1}^{n} \sum_{j=1}^{m} M_{g^{i}}^{j}\right]$ can be obtained by performing the fuzzy addition operation of $M_{g^{i}}^{j}(j=1,2, \ldots, m$.$) such that$

$$
\left[\sum_{i=1}^{n} \sum_{j=1}^{m} M_{g^{i}}^{j}\right]=\left(\sum_{i=1}^{n} l_{i}, \sum_{i=1}^{n} m_{i}, \sum_{i=1}^{n} u_{i}\right)
$$

and $\left[\sum_{i=1}^{n} \sum_{j=1}^{m} M_{g^{i}}^{j}\right]^{-1}$ can be calculated by the inverse of Eq. (3), as follows:

$$
\left[\sum_{i=1}^{n} \sum_{j=1}^{m} M_{g^{i}}^{j}\right]^{-1}=\left(\frac{1}{\sum_{i=1}^{n} u_{i}}, \frac{1}{\sum_{i=1}^{n} m_{i}}, \frac{1}{\sum_{i=1}^{n} l_{i}}\right)
$$

Step 2: As $M_{1}=\left(l_{1}, m_{1}, u_{1}\right)$ and $M_{2}=\left(l_{2}, m_{2}, u_{2}\right)$ are two triangular fuzzy numbers, the degree of possibility of $M_{2}=\left(l_{2}, m_{2}, u_{2}\right) \geq M_{1}=\left(l_{1}, m_{1}, u_{1}\right)$ is defined as

$$
V\left(M_{2} \geq M_{1}\right)=\sup \left\lfloor\min \left(\mu_{\substack{M_{1} \\ y \geq x}}(x), \mu_{M_{2}}(y)\right)\right\rfloor
$$

and can be expressed as in Equation (6):

$$
V\left(M_{2} \geq M_{1}\right)=\operatorname{hgt}\left(M_{1} \cap M_{2}\right)=\mu_{M_{2}}(d)
$$

Where $d$ is the ordinate of the highest intersection point $\mathrm{D}$ between $\mu_{M 1}$ and $\mu_{M_{2}}$ as in Figure 2 .

$$
\begin{aligned}
& V\left(M_{2} \geq M_{1}\right)=\operatorname{hgt}\left(M_{1} \cap M_{2}\right) \\
& =\left\{\frac{\left(l_{1}-u_{2}\right)}{\left(m_{2}-u_{2}\right)-\left(m_{1}-l_{1}\right)}\right.
\end{aligned}
$$

To compare $M_{1}=\left(l_{1}, m_{1}, u_{1}\right)$ and $M_{2}=\left(l_{2}, m_{2}, u_{2}\right)$, we need both values of $V\left(M_{1} \geq M_{2}\right)$ and $V\left(M_{2} \geq M_{1}\right)$. 
This paper is a preprint of the paper that will appear in the Business Strategy and the Environment journal (2017)

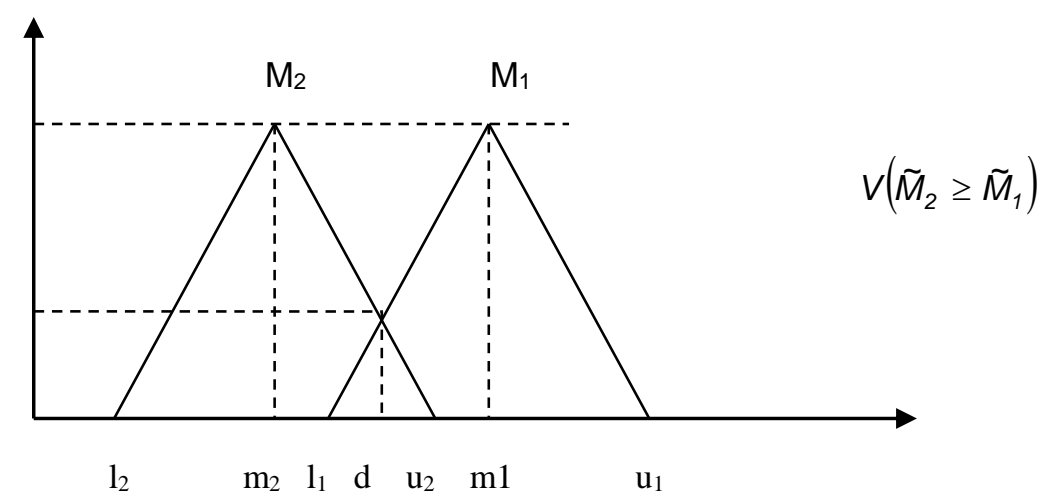

Figure 2: Comparison between Two Triangular Fuzzy Numbers $M_{1}$ and $M_{2}$

Step 3: The degree of possibility for a convex fuzzy number to be greater than $k$ convex fuzzy numbers $M_{i}(i=1,2, \ldots, k)$ can be defined as:

$$
\begin{gathered}
V\left(M \geq M_{1}, M_{2}, \ldots, M_{k}\right)=V\left[\left(M \geq M_{1}\right) \text { and }\left(M \geq M_{2}\right) \text { and } \ldots \text { and }\left(M \geq M_{k}\right)\right] \\
=\min V\left(M \geq M_{i}\right), i=1,2, \ldots, k
\end{gathered}
$$

Assume that

$$
d\left(A_{i}\right)=\min V\left(S_{i} \geq S_{k}\right) \quad \text { for } k=1,2, \ldots, n ; k \neq i .
$$

Then, the weight vector is given by

$$
W^{\prime}=\left(d^{\prime}\left(A_{1}\right), d^{\prime}\left(A_{2}\right), \ldots, d^{\prime}\left(A_{n}\right)\right)^{T}
$$

where $A_{i}(i=1,2, \ldots, n)$ are the $n$ elements.

Step 4: The normalized weight vectors are

$$
W=\left(d\left(A_{1}\right), d\left(A_{2}\right), \ldots, d\left(A_{n}\right)\right)^{T}
$$

where $W$ is a non-fuzzy number.

To establish the fuzzy decision matrix, each decision maker develops an evaluation procedure using the linguistic variables shown in Table 2.

\section{Table 2: Linguistic Variables for Criteria Evaluation}

\begin{tabular}{|l|l|}
\hline Very poor(VP) & $(0,0,1)$ \\
\hline Poor(P) & $(0,1,3)$ \\
\hline Medium poor(MP) & $(1,3,5)$ \\
\hline Fair(F) & $(3,5,7)$ \\
\hline
\end{tabular}


This paper is a preprint of the paper that will appear in the Business Strategy and the Environment journal (2017)

\begin{tabular}{|l|l|}
\hline Medium good(MG) & $(5,7,9)$ \\
\hline Good(G) & $(7,9,10)$ \\
\hline Very good(VG) & $(9,10,10)$ \\
\hline
\end{tabular}

The fuzzy TOPSIS purpose is to find the order of preference of various improvement alternatives that are closest to the positive ideal solution and farthest from the negative ideal solution (Hsieh et al., 2006; Lin et al., 2008; Joshi et al., 2011). The general fuzzy -TOPSIS process is represented in the following steps:

Step 1: Establish the normalized performance matrix. The purpose of normalizing the performance matrix is to unify the unit of matrix entries. Assume the original performance matrix is:

$$
x=\left(x_{i j}\right) \quad \forall{ }_{i, j}
$$

where $x_{\mathrm{ij}}$ is the performance of the alternative $i$ with respect to criterion $j$.

Step 2: Create the weighted normalized performance matrix

TOPSIS defines the weighted normalized performance matrix as:

$$
\begin{array}{ll}
V=\left(V_{i j}\right) & \forall_{i, j} \\
V_{i j}=w_{i j} \times r_{i j} & \forall_{i, j}
\end{array}
$$

where $w_{j}$ is the weight of criterion $j$.

Step 3: Determine the positive and negative ideal solutions

The ideal solution is computed based on the following equations:

$$
\begin{aligned}
& A^{+}=\left\{\left(\max V_{i j} / j \in J\right),\left(\min V_{i j} / j \in J^{\prime}\right), i=1,2, \ldots ., m\right\} \\
& A=\left\{\left(\min V_{i j} / j\right),\left(\min V_{i j} / j \in J^{\prime}\right), i=1,2, \ldots ., m\right\}
\end{aligned}
$$

Where $J=\{j=1,2, \ldots n\}$ and associated with the benefit criteria; $J^{\prime}=\{j=1,2, \ldots n\}, J^{\prime}$ is associated with the cost criteria:

Step 4: Calculate the distance between the positive ideal solution and negative ideal solution for each alternative:

$$
S_{i}^{+}=\sqrt{\sum_{j=1}^{n} w j .\left(V i j-V_{j}^{+}\right)^{2}} i=1,2, \ldots, m
$$


This paper is a preprint of the paper that will appear in the Business Strategy and the Environment journal (2017)

$$
S_{1}=\sqrt{{ }_{j=1}^{n} w j .\left(V_{j} j \quad V_{j}\right)^{2}} \quad i=1,2, \ldots, m
$$

Step 5: Calculate the relative closeness of each alternative to the ideal solution

$$
C_{i}^{+}=\frac{S_{1}}{S_{1}^{+}+S_{1}} \quad i=1,2, \ldots, m
$$

where the index value of $C_{i}^{+}$lies between 0 and $1 . S_{i}^{+}$is ideal separation and $S_{i}^{-}$is the negative ideal separation. The larger the index value, the better the performance of the alternative.

Step 6: Rank the preference order

Using the graded mean integration representation (GMIR) method, we can calculate the closeness coefficient of alternative $\mathrm{A}_{\mathrm{i}}, i=1,2, \ldots m$ as follows:

$$
C C_{i}^{+}=\frac{C i 1+4 C i 2+C i 3}{6} \quad i=1,2, \ldots, m
$$

Calculate the weights $\mathrm{C}_{\mathrm{i}}{ }^{*}$ of criteria. Using a fuzzy linear normalization method, we obtain the $\mathrm{C}_{\mathrm{i}}^{*}$ values. The ranges of $\mathrm{C}_{\mathrm{i}}^{*}$ are in the interval $[0,1]$.

\section{Development of the Criteria Hierarchy Framework}

Based on the literature review, the four original perspectives of BSC are taken as the framework to develop performance evaluation indexes addressing sustainability. FAHP is used to obtain the fuzzy weights of the indexes (criteria). FTOPSIS is developed to evaluate the bank performances and to rank the banks accordingly.

From the four BSC perspectives, 41 evaluation indexes related to banking performance are identified in the literature. Questionnaires are then used in screening the indexes that fit to the banking performance evaluation. At the end, 32 evaluation indexes are selected by the committee of experts. The latter is comprised of eight professional experts from an Indian government financial regulatory body (i.e., the Reserve Bank of India) and Indian banks; it includes three regional board members from the Board of Financial Supervision (BFS) and five experts from banks i.e., deputy general manager, general manager, vice president from operations department, and department of financial services. These experts are individually interviewed to collect the necessary qualitative and quantitative criteria and sub-criteria needed for the present study. The hierarchical framework of the BSC performance evaluation criteria 
This paper is a preprint of the paper that will appear in the Business Strategy and the Environment journal (2017)

(i.e., four dimensions and 32 indexes) is shown in Figure 3. The evaluation indexes are grouped under the four BSC dimensions, "FS: Financial Stability" that includes the criteria FS1-FS8, "CRM: Customer Relationship Management" that includes the criteria CRM1-CRM5, "IBP: Internal Business Process" that is constituted of IBP1-IBP10 criteria, and "EFMS: Environment Friendly Management system" that consists of the EFMS1-EFMS9 criteria. The definitions of criteria and sub-criteria used to evaluate the sustainable bank performances are as follows:

Financial Stability (FS) Financial stability implies that the financial system is robust with respect to the disturbances in terms of financial intermediation, operation of the payment systems and adequate redistribution of the risks (Büyüközkan and Çifçi, 2011, 2012; Govindan et al., 2012). It includes the following sub-criteria:

Liquidity ratio (FS1) - Ability of a company to meet its short-term debt obligations (Cristobal et al., 2007)

Net Assets value per share (FS2) - An expression for net asset value that represents a fund's (mutual, exchange-traded, and closed-end) or a company's value per share

Net Operating margin (FS3) - A ratio used to measure a company's pricing strategy and operating efficiency

Asset/liability ratio (FS4) - The leverage of the company along with the potential risks the company faces in terms of its debt-load

Net profits growth rates (FS5) - A company's total earnings (or profit)

Assets rates of increment (FS6) - An increase in quantity or size, commonly used to refer to the development of large subdivisions in phases

Debt/equity ratio (FS7) - Proportion of equity and debt the company is using to finance its assets Earnings per share of capital (FS8) - The portion of a company's profit allocated to each outstanding share of common stock

Ability to maintain products/service (Bilsel et al., 2006).

Customer Relationship Management (CRM) Customer relationship management based on social exchange and equity significantly assists the banks in developing collaborative, cooperative and profitable long-term relationships. Because of service/product variety and improved quality, customer satisfaction is also increased as well as the relationship closeness and attitudes with customers (Li et al., 2002; Bedell et al., 2004; Bilsel et al., 2006; Cristobal et al., 2007). Following are the sub-criteria:

Customer satisfaction (CRM1) - Products and services supplied by a company meet or surpass customer expectation 
This paper is a preprint of the paper that will appear in the Business Strategy and the Environment journal (2017)

Customer health and safety (CRM2) - Operations are tightly regulated and aim to minimize health and safety risks, wherever possible, at every stage of the customer journey

Reputation and position in the market (CRM3) - Knowledge of the banks, site, rewardsadvertisement, availability of links to other bank institutions

Ability to maintain product/service (CRM4) - A firm employing a product orientation is chiefly concerned with the quality of its own product. A firm would also assume that as long as its product was of a high standard, people would buy it

Customer retention rate (CRM5) - The bank's ability to attract and retain new customers is not only related to its product or services, but also to the way it services its existing customers and the reputation it creates within and across the marketplace.

Internal Business Process (IBP) As per Internal Business Process, the bank must excel at satisfying both its shareholders and customers (Bilsel et al., 2006; Cristobal et al., 2007; Grigoroudis et al., 2008; Baskaran et al., 2012).

Knowledge of the market (IBP1) - The organization has an articulated strategy and the direction of the business is coherent

Information systems (IBP2) - The capability of the information system in support of business processes. An information system can also be considered as a semi-formal language, which supports human decision making and action

Use of electronic data interchanged, ERP, E-sourcing (IBP3)- Competitiveness of transferring electronic documents or business data from one computer system to another, i.e., from one trading partner to another without human intervention

Networking resources available to achieve high level service in a short time (IBP4)- Technology development to meet current and future demand of the firm

Responsiveness (IBP5) - Willingness to respond to customer needs by answering their phone or email requests quickly, by acknowledging them quickly in-person and willing to do what it takes to respond effectively to a service request

Culture of customer service (IBP6) - Willingness and availability of help - frequently asked questions, individualized attention to customers, adapting customers' histories (care and guidelines to the customers)

Social responsibility (IBP7) - The autonomous social responsibility of the banks towards environment protection; Energy consumption

Employment diversity and opportunity (IBP8) - Nature, scope, and effectiveness of any organization and practices that assess and manage the impacts of operations on communities, including entering, operating and existing 
This paper is a preprint of the paper that will appear in the Business Strategy and the Environment journal (2017)

Labor Management (IBP9) - The responsibility of the bank in respecting the rights of the laborers and prohibiting child labor

Performance history (IBP10) - Financial accounts present a historic perspective on the financial performance of the business.

Environment-friendly Management System (EFMS) Environment-friendly in terms of emissions and pollutions, green management system impact of the banking sector such as the use of energy, environmental certifications such as ISO 14000 and environmental policies (Lee et al., 2009; Baskaran et al., 2012; Cho et al., 2012; Govindan et al., 2012).

Environment-related certificates (EFMS1) - Whether the bank has quality-related certificates, such as ISO 9000 and QS-9000

Waste Management (EFMS2) - The minimization and treatment of waste

Green packaging (EFMS3) - The level of green materials used in packaging

Green House Management (EFMS4) -The autonomous social responsibility of the banks towards environment protection

Energy consumption (EFMS5) - The control of energy consumption

Air and noise pollution (EFMS6) - To prevent harmful effects on the environment and health by reducing air and noise pollution

Green process planning (EFMS7) - The level of green process planning of the supplier Capability of preventing pollution (EFMS8) - Capability of product design and manufacturing tools of the supplier to prevent pollution

Natural Resources Management (EFMS9) - The management of natural resources such as land, water, soil, plants and animals, with particular focus on how management affects the quality of life for both present and future generations. 
This paper is a preprint of the paper that will appear in the Business Strategy and the Environment journal (2017)

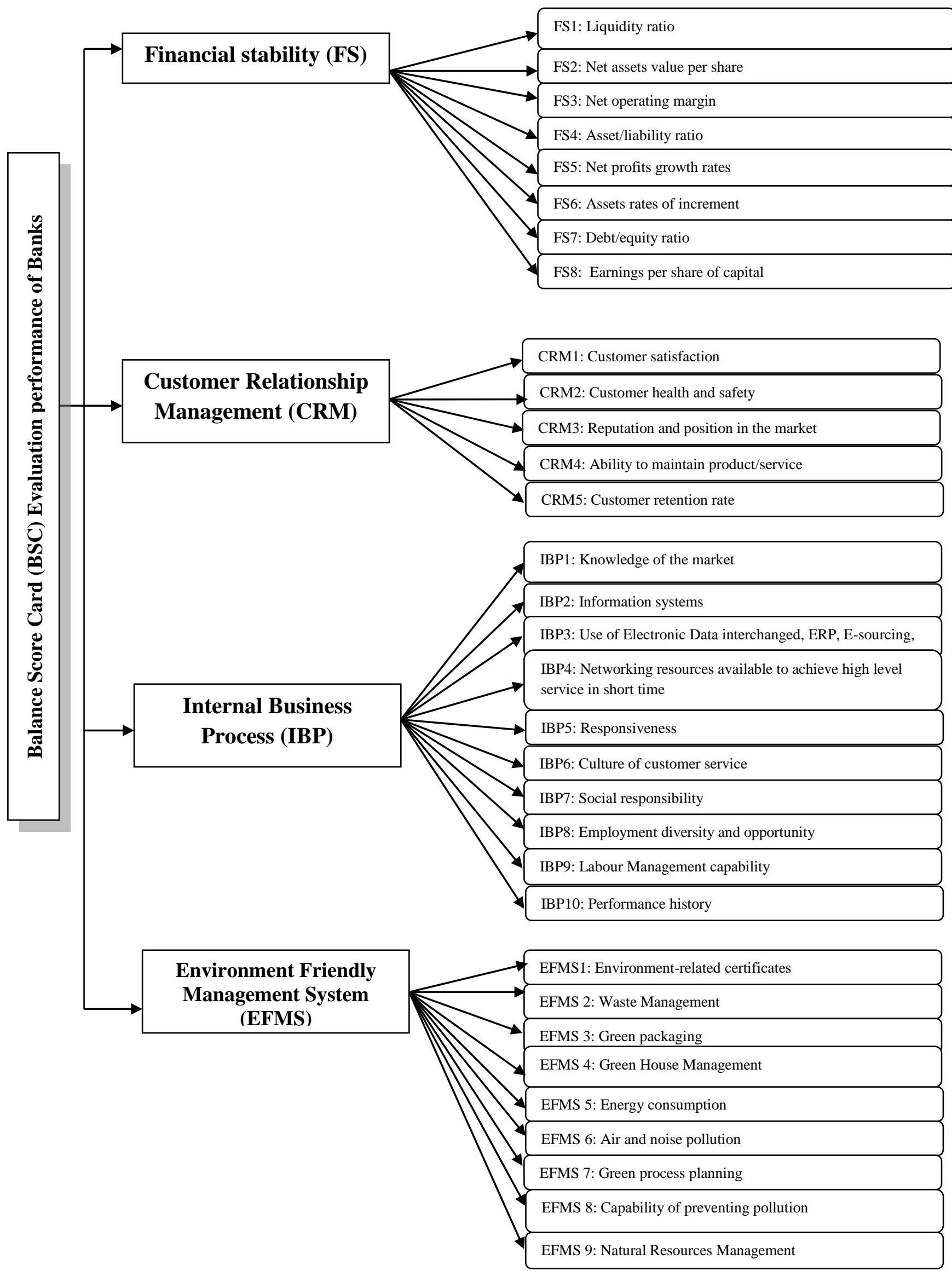


This paper is a preprint of the paper that will appear in the Business Strategy and the Environment journal (2017)

\section{Application of the Approach to the Indian Banking Service}

Financial institutions are densely distributed in India. Financial liberalization and internationalization have been heavily advocated in India over the past decade in response to increased global competition and continuous deregulation. The top finance companies are playing a key role in the growth of the Indian economy. The sustenance of the growth of economy is the primary factor for the development of the Indian financial sector. Private banks have increased their incomes and asset sizes, and outperformed their public sector counterparts in many areas. The network of private sector banks grew at almost three times that of all scheduled commercial banks and more than four times that of public sector banks (www.rbi.gov.in). The star performers among these banks are the Centurion Bank of Punjab (CBoP), State Bank of India, Punjab National Bank, HDFC Bank, ICICI Bank, and the Axis Bank (formerly UTI Bank). The current trend in the banking sector is the increase in staff strength by private sector banks, while the public sector banks witnesses a decline in the number of employees. The private sector banks recorded a compounded growth in their staff strength. The decline in public sector bank staff can be attributed to restructuring and adoption of IT infrastructure. The private sector recorded a growth ranging from $30 \%$ to $68 \%$ in terms of capital, reserves and surplus. The deposits increased in the range of $32 \%$ to $51 \%$, while the advances showed a growth trend between $39 \%$ to $71 \%$.

However, these figures only concern the economic perspective of the performance and the growth and very scarce information is available regarding the environmental and the societal perspectives. For this reason, the expert inputs are valuable and their vagueness is tackled by using fuzzy representations. The objective of the case study is to apply the proposed approach to evaluate and rank the six banks as per the sustainability framework in the Indian context. Three decisionmakers are asked to participate in the evaluation process D1, D2, and D3 - consisting of two regional directors and one member from the Board of Financial Supervision (BFS).

\section{Weights of the Evaluation Criteria}

Based on the hierarchical framework of the BSC performance evaluation indexes, a FAHP questionnaire using TFN is distributed among the experts to develop a pairwise comparison between the criteria (see Appendix-1). The FAHP is adapted to our case as it captures the logic of humans in the comparison between criteria and focuses on the relative importance of the evaluation criteria of the banking performance. The decision makers are asked to use the rating scale of Table 1 to score the performance level of each alternative with respect to each criterion and sub-criterion (see Appendix-2). The results are reported in Table 3. The second column of 
This paper is a preprint of the paper that will appear in the Business Strategy and the Environment journal (2017)

Table 3 provides the local weights of each sub-criterion expressed as TFNs. Moreover, the global weights of the sub-criteria, taking into account the criteria comparison, are reported in the third column. The fourth column of the table shows the best non-fuzzy performance weights of each sub-criterion calculated as $[(\mathrm{u}-1)+(\mathrm{m}-1)] / 3+1$. 
Table 3: Fuzzy Weights of Balance Score Card Performance Evaluation Index by Fuzzy Analytic Hierarchy Process

\begin{tabular}{|c|c|c|c|c|c|c|c|c|c|}
\hline \multicolumn{2}{|c|}{$\begin{array}{c}\text { Criterion } \\
\text { (Dimension and } \\
\text { index) }\end{array}$} & \multicolumn{3}{|c|}{ Local Weights } & \multicolumn{3}{|c|}{ Global weights } & \multirow[t]{2}{*}{$\begin{array}{l}\text { Best non-fuzzy } \\
\text { performance } \\
\text { weights }\end{array}$} & \multirow{2}{*}{$\begin{array}{l}\text { Ranking } \\
1\end{array}$} \\
\hline FS & & 10.274383092 & 0.334768624 & $0.390426273)$ & & & & & \\
\hline & FS1 & 0.206145943 & 0.235879444 & 0.247942517 & 0.056563 & 0.078965 & 0.096803 & 0.077443757 & \\
\hline & FS2 & 0.20690127 & 0.224954583 & 0.230567814 & 0.0567702 & 0.075308 & 0.09002 & 0.07403256 & \\
\hline & FS3 & 0.127036693 & 0.135047311 & 0.134779133 & 0.0348567 & 0.04521 & 0.052621 & 0.044229212 & \\
\hline & FS4 & 0.084392848 & 0.089261009 & 0.137324769 & 0.023156 & 0.029882 & 0.053615 & 0.035550984 & \\
\hline & FS5 & 0.091670018 & 0.097982915 & 0.086562808 & 0.0251527 & 0.032802 & 0.033796 & 0.030583568 & \\
\hline & FS6 & 0.101673929 & 0.090123202 & 0.076036619 & 0.0278976 & 0.03017 & 0.029687 & 0.029251574 & \\
\hline & FS7 & 0.096787949 & 0.071662206 & 0.054594723 & 0.026557 & 0.02399 & 0.021315 & 0.02395415 & \\
\hline & FS8 & 0.08539135 & 0.05508933 & 0.032191617 & 0.0234299 & 0.018442 & 0.012568 & 0.018146858 & \\
\hline \multirow[t]{6}{*}{ CRM } & & 0.270543683 & 0.283368061 & 0.285806801 & & & & & 2 \\
\hline & CRM1 & 0.248632748 & 0.296369601 & 0.341793762 & 0.067266 & 0.083982 & 0.097687 & 0.082978227 & \\
\hline & CRM2 & 0.258904205 & 0.273442162 & 0.277488926 & 0.0700449 & 0.077485 & 0.079308 & 0.075612632 & \\
\hline & CRM3 & 0.20096629 & 0.190398287 & 0.178409817 & 0.0543702 & 0.053953 & 0.050991 & 0.053104564 & \\
\hline & CRM4 & 0.162158344 & 0.139467841 & 0.123129447 & 0.0438709 & 0.039521 & 0.035191 & 0.039527627 & \\
\hline & CRM5 & 0.129338413 & 0.100322109 & 0.079178048 & 0.0349917 & 0.028428 & 0.02263 & 0.028683132 & \\
\hline \multirow[t]{4}{*}{ IBP } & & 0.307799122 & 0.263443322 & 0.224096962 & & & & & 3 \\
\hline & IBP1 & 0.146663841 & 0.176163656 & 0.202198925 & 0.045143 & 0.046409 & 0.045312 & 0.045565047 & \\
\hline & IBP2 & 0.14285431 & 0.163991198 & 0.175074398 & 0.0439704 & 0.043202 & 0.039234 & 0.042135486 & \\
\hline & IBP3 & 0.103624856 & 0.1128427 & 0.120126712 & 0.0318956 & 0.029728 & 0.02692 & 0.029514442 & \\
\hline
\end{tabular}


This paper is a preprint of the paper that will appear in the Business Strategy and the Environment journal (2017)

\begin{tabular}{|c|c|c|c|c|c|c|c|c|c|}
\hline & IBP4 & 0.110573624 & 0.10537614 & 0.105962428 & 0.0340345 & 0.027761 & 0.023746 & 0.028513654 & \\
\hline & IBP5 & 0.106710968 & 0.103699296 & 0.100563613 & 0.0328455 & 0.027319 & 0.022536 & 0.02756681 & \\
\hline & IBP6 & 0.104194103 & 0.095351519 & 0.086035672 & 0.0320709 & 0.02512 & 0.01928 & 0.025490302 & \\
\hline & IBP7 & 0.086600641 & 0.07642175 & 0.06900004 & 0.0266556 & 0.020133 & 0.015463 & 0.020750367 & \\
\hline & IBP8 & 0.079028142 & 0.07009012 & 0.062517904 & 0.0243248 & 0.018465 & 0.01401 & 0.018933213 & \\
\hline & IBP9 & 0.075047734 & 0.060590583 & 0.049356686 & 0.0230996 & 0.015962 & 0.011061 & 0.016707498 & \\
\hline & IBP10 & 0.04470178 & 0.035473039 & 0.029163622 & 0.0137592 & 0.009345 & 0.006535 & 0.009879928 & \\
\hline \multirow[t]{10}{*}{ EFMS } & & 0.147274104 & 0.118419993 & 0.0996699665 & & & & & 4 \\
\hline & EFMS1 & 0.139527769 & 0.174686138 & 0.206822859 & 0.0205488 & 0.020686 & 0.020614 & 0.020616395 & \\
\hline & EFMS2 & 0.159436057 & 0.179047901 & 0.191251229 & 0.0234808 & 0.021203 & 0.019062 & 0.021248552 & \\
\hline & EFMS3 & 0.123703168 & 0.133543625 & 0.140200919 & 0.0182183 & 0.015814 & 0.013974 & 0.01600211 & \\
\hline & EFMS4 & 0.108192209 & 0.110445439 & 0.111559372 & 0.0159339 & 0.013079 & 0.011119 & 0.015337155 & \\
\hline & EFMS5 & 0.1159988005 & 0.109800775 & 0.103663105 & 0.0170836 & 0.013003 & 0.010332 & 0.013472775 & \\
\hline & EFMS6 & 0.104272906 & 0.092415336 & 0.083223547 & 0.0153567 & 0.010944 & 0.008295 & 0.011531803 & \\
\hline & EFMS7 & 0.101800857 & 0.083657473 & 0.069562181 & 0.0149926 & 0.009907 & 0.006933 & 0.010610869 & \\
\hline & EFMS8 & 0.065243238 & 0.054274297 & 0.04658704 & 0.0096086 & 0.006427 & 0.004643 & 0.006893043 & \\
\hline & EFMS9 & 0.081824992 & 0.062129016 & 0.047129749 & 0.0120507 & 0.007357 & 0.004697 & 0.008035147 & \\
\hline Total & & & & & & & & 1.00 & \\
\hline
\end{tabular}


This paper is a preprint of the paper that will appear in the Business Strategy and the Environment journal (2017)

Results of the FAHP analysis reveal that the most important evaluation indices are the Financial Stability criteria, with a weight equal to the TFN $(0.2743,0.3347,0.3904)$, the Customer Relationship Management with a weight equal to the TFN $(0.2705,0.2833,0.2858)$, the Internal Business Process with a weight equal to the TFN $(0.3077,0.2634,0.2240)$ and finally the environment-friendly management system with a weight equal to the TFN $(0.1472,0.1184$, 0.0996). It is then clear that the environmental issues have minor interest with respect to the three 'standard' performances of the BSC. A similar procedure is carried out to calculate the weights of the sub-criteria. The results are reported in Table 3. The explanation of these results is linked with the fact that banking performance is strongly connected to these three criteria.

A comparison of all the 32 sub-criteria shows that the most important sub-criterion is customer satisfaction, followed by liquidity ratio and customer health and safety. It may be noted that even though the model is developed to evaluate sustainable banking activities, many non-sustainable and non-environmental criteria and sub-criteria have relatively high preferences. In particular, six out of the top ten sub-criteria are non-green and non-environmental sub-criteria. Environmentfriendly management system and sustainable development require more emphasis in the bank industry.

\section{Ranking of the Banking Performances}

The six banks considered as the alternatives (e.g. A1, A2, A3, A4, A5, and A6) taken as an illustrative example are evaluated by the experts based on the selected evaluation criteria. To ensure that the integrated opinions are consistent, the integrated fuzzy matrix obtained is defuzzified using Eq.18. Since different natures of the alternatives have different assessment standards, decision-makers are required to define their assessment standard before the selection of improvement alternatives. Tables 4 and 5 display the decision matrix for the selection of alternatives using FTOPSIS based on decision factors scale as defined in Table 2.

Table 4: Ratings of the six Alternatives by Decision-makers under each Criterion

\begin{tabular}{|l|l|l|l|l|}
\hline Criteria & Alternative & \multicolumn{3}{|c|}{ Decision-Makers } \\
\hline FS & & D1 & D2 & D3 \\
\hline & A1 & G & G & G \\
\hline & A2 & VG & VG & VG \\
\hline & A3 & G & G & MG \\
\hline & A4 & MG & G & VG \\
\hline & A5 & VG & MG & G \\
\hline
\end{tabular}


This paper is a preprint of the paper that will appear in the Business Strategy and the Environment journal (2017)

\begin{tabular}{|l|l|l|l|l|} 
& A6 & G & VG & MG \\
\hline CRM & & & & \\
\hline & A1 & VG & G & MG \\
\hline & A2 & G & G & MG \\
\hline & A3 & VG & VG & VG \\
\hline & A4 & F & G & G \\
\hline & A5 & G & G & F \\
\hline & A6 & F & F & MG \\
\hline IBP & & & & \\
\hline & A1 & P & MP & F \\
\hline & A2 & MG & G & MP \\
\hline & A3 & G & MP & P \\
\hline & A4 & MP & P & MP \\
\hline & A5 & MG & G & G \\
\hline & A6 & MP & P & P \\
\hline EFMS & & & & \\
\hline & A1 & MP & P & P \\
\hline & A2 & MG & G & VG \\
\hline & A3 & MG & G & G \\
\hline & A4 & MP & F & F \\
\hline & A5 & MP & P & F \\
\hline & A6 & MG & G & G \\
\hline
\end{tabular}

The ratings of these six alternatives by the decision-makers under each criterion and the aggregated fuzzy decision matrix of the group are presented in Tables 5 and 6, respectively. Table 6 shows the weighted normalized decision matrix along with the calculated distance of all alternatives to the positive ideal solution $(\mathrm{Si}+)$ and the negative ideal solution $\left(\mathrm{Si}^{-}\right)$calculated according to the procedure presented in Section 3. The relative closeness $\mathrm{CC}_{\mathrm{i}}$ and $\mathrm{C}_{\mathrm{i}}^{*}$ values for the six banks are found to be $\mathrm{A} 6=(6.88,1.02), \mathrm{A} 4=(6.72,1.00), \mathrm{A} 3=(6.69,1.00), \mathrm{A} 3=(6.46$, 0.96), $\mathrm{A} 5=(5.92,0.88)$, and $\mathrm{A} 2=(5.72,0.85)$, respectively. This implies that $\mathrm{A} 6$ has the smallest gap for achieving the aspired/desired level among the six banks, whereas A2 has the largest gap. The performances of banks with respect to each criterion are shown in Figure. 4. Table 6 shows that the bank A6 performs the best under all criteria within the sustainability context, even if it is closely followed by both A1 and A4.

Table 5: The normalized Fuzzy Decision Matrix and Fuzzy Importance Weight of Criteria 
This paper is a preprint of the paper that will appear in the Business Strategy and the Environment journal (2017)

\begin{tabular}{|l|l|l|l|l|l|l|l|l|l|l|l|l|}
\hline & \multicolumn{3}{|c|}{ FS } & \multicolumn{3}{c|}{ CRM } & \multicolumn{3}{c|}{ IBP } & \multicolumn{3}{c|}{ EFMS } \\
\hline A1 & 0.39 & 0.41 & 0.42 & 0.44 & 0.44 & 0.43 & 0.16 & 0.25 & 0.32 & 0.04 & 0.12 & 0.22 \\
\hline A2 & 0.51 & 0.46 & 0.42 & 0.40 & 0.42 & 0.43 & 0.52 & 0.52 & 0.51 & 0.60 & 0.54 & 0.49 \\
\hline A3 & 0.36 & 0.38 & 0.40 & 0.57 & 0.50 & 0.44 & 0.32 & 0.36 & 0.38 & 0.53 & 0.52 & 0.49 \\
\hline A4 & 0.39 & 0.40 & 0.40 & 0.36 & 0.39 & 0.40 & 0.08 & 0.19 & 0.27 & 0.25 & 0.32 & 0.37 \\
\hline A5 & 0.39 & 0.40 & 0.40 & 0.36 & 0.39 & 0.40 & 0.77 & 0.69 & 0.61 & 0.14 & 0.22 & 0.30 \\
\hline A6 & 0.39 & 0.40 & 0.40 & 0.23 & 0.29 & 0.34 & 0.04 & 0.14 & 0.23 & 0.53 & 0.52 & 0.49 \\
\hline Weights & 0.51 & 0.46 & 0.42 & 0.57 & 0.50 & 0.44 & 0.77 & 0.69 & 0.61 & 0.60 & 0.54 & 0.49 \\
\hline
\end{tabular}

Table 6: Final Evaluation of the Banks

\begin{tabular}{|c|c|c|c|c|c|c|c|c|c|c|c|c|}
\hline & \multicolumn{3}{|c|}{$S i-$} & \multicolumn{3}{|c|}{$S i+$} & \multicolumn{3}{|c|}{$\mathrm{C}_{\mathrm{i}}=\mathrm{S}_{\mathrm{i}-} / \mathrm{S}_{\mathrm{i}}+\mathrm{S}_{\mathrm{i}^{-}}$} & \multirow{2}{*}{$\begin{array}{l}\mathrm{CCi}= \\
\mathrm{C}_{\mathrm{i} 1}+\mathbf{4} \mathrm{C}_{\mathrm{i} 2}+\mathrm{C}_{\mathrm{i} 3} / \mathbf{6} \\
6.69\end{array}$} & \multirow{2}{*}{$\begin{array}{l}\mathbf{C}_{\mathrm{i}}^{*} \\
1.00\end{array}$} & \multirow{2}{*}{$\begin{array}{c}\text { Ranking } \\
3\end{array}$} \\
\hline A1 & 0.13 & 0.10 & 0.06 & 0.41 & 0.27 & 0.16 & 1.41 & 1.27 & 1.16 & & & \\
\hline A2 & 0.36 & 0.26 & 0.16 & 0.16 & 0.10 & 0.05 & 1.16 & 1.10 & 1.05 & 5.72 & 0.85 & 6 \\
\hline A3 & 0.30 & 0.21 & 0.12 & 0.35 & 0.23 & 0.14 & 1.35 & 1.23 & 1.14 & 6.46 & 0.96 & 4 \\
\hline A4 & 0.11 & 0.09 & 0.06 & 0.42 & 0.28 & 0.17 & 1.42 & 1.28 & 1.17 & 6.72 & 1.00 & 2 \\
\hline A5 & 0.41 & 0.29 & 0.18 & 0.22 & 0.13 & 0.07 & 1.22 & 1.13 & 1.07 & 5.92 & 0.88 & 5 \\
\hline A6 & 0.19 & 0.14 & 0.09 & 0.44 & 0.31 & 0.19 & 1.44 & 1.31 & 1.19 & 6.88 & 1.02 & 1 \\
\hline
\end{tabular}

\section{Discussion and Conclusion}

Regarding the sustainability issues, it is shown that the environment-friendly management system takes a backseat compared to the three other criteria of the BSC. This is certainly expected, as the decision-makers are less conscious of the environmental issues in the service industry than in other domains such as the manufacturing industry. Furthermore, one of the main reasons of superiority of A6 over A1 and A4 is its consideration of environmental issues, which is acknowledged by the experts in their evaluations. However, this advantage is too small to provide a significant competitive edge. Indeed, the sustainability issues in banking services in India are not given due importance for an emerging country. This is explicitly observed through the weight provided to the natural resource management sub-criterion, which is underestimated compared to other EFMS sub-criteria.

Furthermore, it is expected that corporate responsibility in banking (IBP 7 sub-criterion) attracts more attention in the evaluation done by the DMs. However, the evaluation shows a different situation as it is ranked $3^{\text {rd }}$ over 4 in the evaluation of the BSC perspectives. This result is actually specific to the Indian banking sector that is less demanding than other sectors such as 
This paper is a preprint of the paper that will appear in the Business Strategy and the Environment journal (2017)

manufacturing (considered to be more important in terms of corporate responsibility). Moreover, there is a misunderstanding of the role that corporate social responsibility plays with respect to environmental issues. In fact, in some reports and datasets, the environmental perspective is considered as part of the corporate social responsibility (CSR HUB, 2013). Not only this can increase the corporate social responsibility weight compared to other criteria, but it can also hide the real environmental impact of the banking service industry.

One of the main observations drawn on the managerial side is the lack of common methodologies and standards addressing sustainability in the banking service, despite the existence of many general standards such as TBL, ISO and Global Reporting Initiative. One of the reasons is linked to the suspicion of manipulation of data from the financial institutions in periods of crisis to hide the real performances and to lower the actual impact of the financial activities on sustainability. Another reason could be the absence of sustainability culture in the Indian banking service operations, as sustainability is considered by the firms rather as a constraint than an opportunity. The deregulation of the financial sector is obviously not playing a role in favor of the integration of the sustainability culture in the Indian banks.

The work presents some limitations. The new BSC includes 32 sub-criteria among 41 identified from the literature. Actually, even if this represents a consensus between the three decision makers participating in this work, it is not clear how the sub-criteria dismissed could impact the results if they are all or partly selected. One interesting direction may be to develop a DEA-based approach to tackle the complexity of the integration of the 65 sub-criteria at the BSC level, which can lead to a complete characterization of the sustainability features for the banking industry. Moreover, the development of other decision making approaches tackling the imprecision of the information such as Grey Relational Analysis (GRA) is foreseen. It is expected that GRA can take into account many factors and less data and can overcome the disadvantages of statistical methods or the fully evaluation-based techniques.

\section{Appendix-1}

Note- Listed below are sample questionnaires for criteria comparison.

Questionnaire

Importance of a criterion over another

1. How important is financial stability compared with customer relationship management?

2. How important is financial stability compared with internal business process?

3. How important is financial stability compared with environment friendly management system? 
This paper is a preprint of the paper that will appear in the Business Strategy and the Environment journal (2017)

\begin{tabular}{|l|c|l|l|l|}
\cline { 2 - 5 } \multicolumn{1}{c|}{} & $\begin{array}{l}\text { Financial } \\
\text { Stability }\end{array}$ & $\begin{array}{l}\text { Customer } \\
\text { Relationship } \\
\text { management }\end{array}$ & $\begin{array}{l}\text { Internal Business } \\
\text { Process }\end{array}$ & $\begin{array}{l}\text { Environment Friendly } \\
\text { Management System }\end{array}$ \\
\hline Financial stability & $\mathbf{1}$ & & & \\
\hline $\begin{array}{l}\text { Customer Relationship } \\
\text { Management }\end{array}$ & & $\mathbf{1}$ & $\mathbf{1}$ & \\
\hline $\begin{array}{l}\text { Internal Business Process } \\
\text { Environment Friendly } \\
\text { Management System }\end{array}$ & & & & $\mathbf{1}$ \\
\hline
\end{tabular}

Using the following evaluation marks

\begin{tabular}{|c|l|}
\hline $1,1,1$ & Equal \\
\hline $2 / 3,1,3 / 2$ & Low \\
\hline $3 / 2,2,5 / 2$ & High \\
\hline $5 / 2,3,7 / 2$ & Very high \\
\hline $7 / 2,4,9 / 2$ & Absolutely important \\
\hline
\end{tabular}

\section{Appendix-2}

Note- Listed below are sample questionnaires for Sub-Criteria

Example of the importance of sub-criteria over other sub-criteria under Financial Stability

With respect to the Financial Stability to find out the best criteria

1. How important is liquidity ratio when it is compared with net assets value per share?

2. How important is liquidity ratio when it is compared with net operating margin?

3. How important is liquidity ratio when it is compared with asset/liability ratio?

4. How important is liquidity ratio when it is compared with net profits growth rates?

5. How important is liquidity ratio when it is compared with assets rates of increments?

6. How important is liquidity ratio when it is compared with debt/equity ratio?

7. How important is liquidity ratio when it is compared with earnings per share of capital?

Financial Stability

\begin{tabular}{|c|c|c|c|c|c|c|c|c|}
\hline & $\begin{array}{l}\text { Liquidity } \\
\text { ratio }\end{array}$ & $\begin{array}{l}\text { Net } \\
\text { assets } \\
\text { value per } \\
\text { share }\end{array}$ & $\begin{array}{l}\text { Net } \\
\text { operating } \\
\text { margin }\end{array}$ & $\begin{array}{l}\text { Asset/ } \\
\text { liability } \\
\text { ratio }\end{array}$ & $\begin{array}{l}\text { Net } \\
\text { profits } \\
\text { growth } \\
\text { rates }\end{array}$ & $\begin{array}{l}\text { Assets } \\
\text { rates of } \\
\text { increments }\end{array}$ & $\begin{array}{l}\text { Debt/ } \\
\text { Equity } \\
\text { ratio }\end{array}$ & $\begin{array}{l}\text { Earnings } \\
\text { per share } \\
\text { of capital }\end{array}$ \\
\hline Liquidity ratio & 1 & & & & & & & \\
\hline $\begin{array}{l}\text { Net assets value } \\
\text { per share }\end{array}$ & & 1 & & & & & & \\
\hline $\begin{array}{l}\text { Net operating } \\
\text { Margin }\end{array}$ & & & 1 & & & & & \\
\hline
\end{tabular}


This paper is a preprint of the paper that will appear in the Business Strategy and the Environment journal (2017)

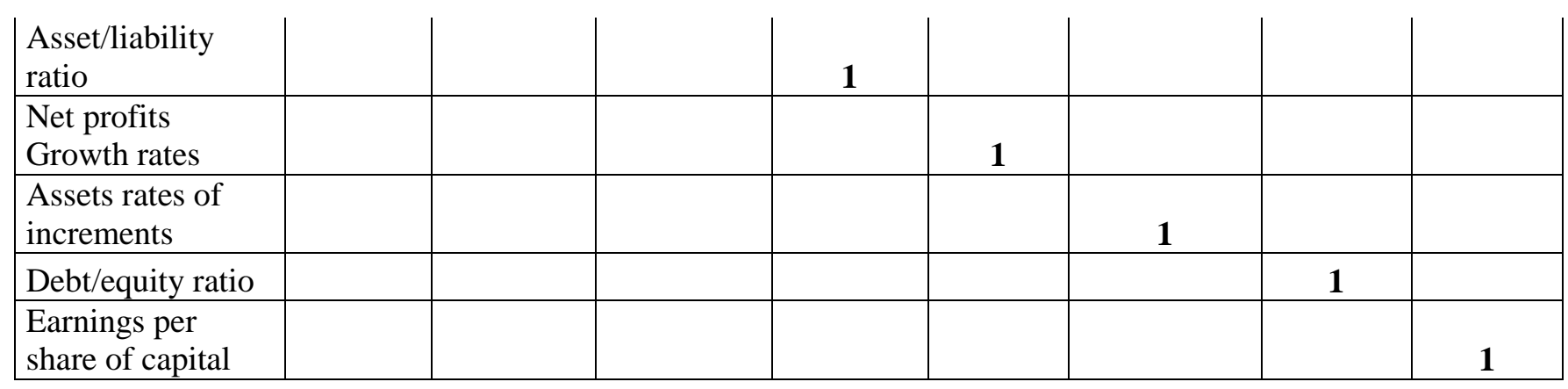

\section{References}

Albayrak, E., Erensal, Y.C., 2005. A study bank selection decision in Turkey using the extended fuzzy AHP method. In 35th International conference on computers and Industrial engineering, Istanbul, Turkey.

Anderson, W., Jr., Cox, J.E.P., Fulcher, D., 1976. Bank selection decisions and marketing segmentation. Journal of Marketing 40(1), 40-45.

Arshadi, N., Lawrence, E.C., 1987. An empirical investigation of new bank performance. Journal of Banking and Finance 11(1), 33-48.

Athanassopoulos, A., Giokas, D., 2000. On-going use of data envelopment analysis in banking institutions: Evidence from the Commercial Bank of Greece. Interfaces 30(2), 81-95.

Awasthi, A., Chauhan, Satyaveer S., Omrani, H., Panahi, A., 2011. A hybrid approach based on SERVQUAL and fuzzy TOPSIS for evaluating transportation service quality. Computers and Industrial Engineering 61(3), 637-646.

Ayag , Z., Özdemir, R. G., 2006. A fuzzy AHP approach to evaluating machine tool alternatives. Journal of Intelligent Manufacturing 17, 179-190.

Azzone, G., Masella, C., Bertele, U., 1991. Design of performance measures for time-based companies. International Journal of Operations and Production Management 11(3), 77-85.

Baskaran, V., Nachiappan, S., Rahman, S., 2012. Indian textile suppliers' sustainability evaluation using the grey approach. International Journal of Production Economics 135, 647-658.

Beccalli, A., 2007. Does IT investment improve bank performance? Evidence from Europe. Journal of Banking and Finance 31, 2205-2230.

Bedell, S.E., Agrawal, A., Petersen, L.E., 2004. A systematic critique of diabetes on the world wide web for patients and their physicians. International Journal of Medical Informatics 73, 687-694.

Bhattacharya, C.B., Sen, S. 2004. Doing better at doing good: when, why and how consumers respond to corporate social initiatives, California Management Review, 47(1), 9-24.

Bieker, T., Waxenberger, B., 2002. Sustainability balanced scorecard and business ethics. In Paper presented at the greening of industry network conference 2002, Goteborg, Sweden.

Bilsel, R.U., Buyukozkan, G., Ruan, D., 2006. A fuzzy preference ranking model for a quality evaluation of hospital web sites. International Journal of Intelligent Systems 21, 11811197.

Bititici, U.S., Nudurupati, S.S., 2002. Using performance measurement to derive continuous improvement. Manufacturing Engineer, 81(5), 230-235.

Boiral O., 2006. Global warming: should companies adopt a proactive strategy? Long Range Planning 39,315-330.

Boyd, W., Leonard, M., White, C., 1994. Customer preferences for financial services: An analysis. International Journal of Bank Marketing 12(1), 9-15.

Bragdon, J.,Merlin, J., 1972. Is pollution profitable? Risk Management, April, 9-18. 
This paper is a preprint of the paper that will appear in the Business Strategy and the Environment journal (2017)

Büyüközkan, G., Çifçi, G., 2011. A novel fuzzy multi-criteria decision framework for sustainable supplier selection with incomplete information. Computers in Industry 62, 164-174.

Büyüközkan, G., Çifçi, G., 2012. A combined fuzzy AHP and fuzzy TOPSIS based strategic analysis of electronic service quality in healthcare industry. Expert Systems with Applications 39, 2341-2354

Chan, F.T.S., Chan, H.K., Qi, H.J., 2006. A review of performance measurement systems for supply chain management. International Journal of Business Performance Management 8(2/3), 110-131.

Chan, F.T.S., Qi, H.J., 2003a. An innovative Performance measurement method for supply chain management. Supply Chain Management - An International Journal 8(3), 209-223.

Chan, F.T.S., Qi, H.J., 2003b. Feasibility of Performance measurement system for supply chain: A process-based approach and measures. Integrated Manufacturing Systems 14(3), 179-190.

Chang, Y., 1996. Application of the extent analysis method on fuzzy AHP. European Journal of Operational Research 95, 649-655.

Chia, A., Hoon, H.S., 2000. Adopting and creating balanced scorecards in Singapore-based companies. Singapore Management Review 22(2), 1-15.

Chiou, H.K., Tzeng, G.H., Cheng, D.C., 2005. Evaluating sustainable fishing development strategies using fuzzy MCDM approach. Omega 33(3), 223-234.

Cho, D.W., Lee, Y.H., Ahn, S.H., Hwang, M.K., 2012. A framework for measuring the performance of service supply chain management. Computers and Industrial Engineering $62,801-818$.

Collier, D.A., 1995. Modeling the relationships between process quality errors and overall service process performance. International Journal of Service Industry Management 6(4), 4-19.

Cristobal, E., Flavian, C., Guinaliu, M., 2007. Perceived e-service quality (PeSQ): Measurement validation and effects on consumer satisfaction and web site loyalty. Managing Service Quality 17(3), 317-340.

CSR HUB 2013. http://www.csrhub.com/CSR_and_sustainability_information/State-Bank-ofIndia-Group/, last accessed on May $13^{\text {th }} 2013$.

Dagdeviren, M., Yavuz, S., Kilin, N., 2009. Weapon selection using the AHP and TOPSIS methods under fuzzy environment. Expert Systems with Applications 36, 8143-8151.

Davis, S., Albright, T., 2004. An investigation of the effect of the balanced scorecard implementation on financial performance. Management Accounting Research 15(2), 135153.

Demir, Y., Astarcioglu, M., 2007. Determining bank performance via financial prediction: An application in ISE. Suleyman Demirel University Journal of Business Administration and Economics Faculty 12(1), 273-292.

Denizer, C., Dinc, M., Tarımcilar, M., 2000. Measuring bank efficiency in the pre and post liberatlization environment: Evidence from the Turkish banking system. World Bank Policy Research Working Paper, 2476.

Devlin, J. F., 2002. Customer knowledge and choice criteria in retail banking. Journal of Strategic Marketing 10(4), 273-290.

Devlin, J., Gerrard, P., 2005. A study of customer choice criteria for multiple bank users. Journal of Retailing and Consumer Services 12(4), 297-306.

Drake, L., 2001. Efficiency and productivity change in UK banking. Applied Financial Economics $11,557-571$.

Elkington, J., 1997. Cannibals with Forks: The Triple Bottom Line of Twenty-first Century Business. Capstone, Oxford, UK.

Elliot, M.B., Shatto, D., Singer, C., 1996. Three customer values are key marketing success. Journal of Retail Banking Services 18(1), 1-7.

Evans, N., 2007. Assessing the balanced scorecard as a management tool for hotels. International Journal of Contemporary Hospitality Management 17(5), 376-390. 
This paper is a preprint of the paper that will appear in the Business Strategy and the Environment journal (2017)

Figge, F., Hahn, T., Schaltegger, S., Wagner, M., 2002. The sustainability balanced scorecard Linking sustainability management to business strategy. Business Strategy and the Environment 11(5), 269-284.

Fitzgerald, L., Johnston, R., Brignall, T.J., Silvestro, R., Voss, C., 1991. Perfomance Measurement in Service Businesses. C.I.M.A.

Fortuin, L., 1988. Performance indicators-Why where and how? European Journal of Operational Research 34, 1-9.

Gilligann, T., Smirlock, M., Marshall, W., 1984. Scale and scope economics in the multi-product banking firm. Journal of Monetary Economics 13(3), 393-405.

Giokas, D.I., 1991. Bank branch operating efficiency: A comparative application of DEA and the loglinear model. Omega 19(6), 393-405.

Govindan, K., Khodaverdi, R., Jafarian, A., 2012. A fuzzy multi criteria approach for measuring sustainability performance of a supplier based on triple bottom line approach. Journal of Cleaner Production, 1-10.

Grigoroudis, E., Litos, C., Moustakis, V.A., Politis, Y., Tsironis, L., 2008. The assessment of userperceived web quality: Application of a satisfaction benchmarking approach. European Journal of Operational Research 187, 1346-1357.

Gunasekaran, A., Spalanzani, A., 2012. Sustainability of manufacturing and services: Investigations for research and applications. International Journal Production Economics $140,35-47$.

Hart, S., Milstein, M.B., 2003. Creating sustainable value. Academy of Management Executive 17, 56-67.

Hopwood, A.G., 1972. An empirical study of the role of accounting data in performance evaluation, empirical research in accounting. Supplement to Journal of Accounting Research 10, 156-182.

Hsieh, L.F., Chin, J.B., Wu, M.C., 2006. Performance evaluation for university electronic libraries in Taiwan. The Electronic Library, 24(2), 212-224.

Hsu, Chia-Wei, Hu, Allen H., Chiou, Cherng-Ying, Chen,Ta-Che, 2011. Using the FDM and ANP to construct a sustainability balanced scorecard for the semiconductor industry. Expert Systems with Applications 38, 12891-12899.

Hubbard, G., 2009. Measuring organizational performance: Beyond the triple bottom line. Business Strategy and the Environment 18(3), 177-191.

Hwang, C.L., Yoon, K., 1981. Multiple attribute decision making methods and applications. New York: Springer-Verlag.

Isik, I., Uysal, D., Meleke, U., 2003. Post-entry performance of de novo banks in Turkey. In 10th Annual conference of the ERF. www.erf.org.eg/tenthconf/financial_markets_presented/ ISIK_Uysal_Meleke.pdf>.

Ittner, C., Larcker, D., Randall, T., 2003. Performance Implications of Strategic Performance Measurement in Financial Services Firms. Accounting Organizations and Society 28(7-8), 751-741.

Jabbour L.S., Jabbour, C.J.C., 2009. Are supplier selection criteria going green? Case studies of companies in Brazil. Industrial Management and Data Systems 109(4), 477-495.

Jolai, F., Yazdian, S. A., Shahanaghi, K., Khojasteh, M.A., 2011. Integrating fuzzy TOPSIS and multi-period goal programming for purchasing multiple products from multiple suppliers. Journal of Purchasing and Supply Management 17, 42-53.

Joshi, R., Banwet, D.K., Shankar, R., 2011. A Delphi-AHP-TOPSIS based benchmarking framework for performance improvement of a cold chain. Expert Systems with Applications 38, 10170-10182.

Kahraman, C., Büyüközkan, G., Ates, N.Y., 2007. A two phase multi-attribute decision making approach for new product introduction. Information Sciences 177, 1567-1582.

Kaplan, R. S., Norton, D., 1992. The balanced scorecard measures that drive performance. Harvard Business Review 70(1), 71-79. 
This paper is a preprint of the paper that will appear in the Business Strategy and the Environment journal (2017)

Kaya, Y.T., 2001. CAMELS analysis in Turkish banking sector. BRSA MSPD working report 6. Kim, C.S., Davidson, L. F., 2004. The effects of IT expenditures on banks' business performance: Using a balanced scorecard approach. Managerial Finance 30(6), 28-45.

Kosmidou, K., Pasiouras, F., Doumpos, M., Zopounidis, C., 2006. Assessing performance factors in the UK banking sector: A multicriteria methodology. Central European Journal of Operations Research 14(1), 25-44.

Kuo, M.S., Liang, G.S., Huang, W.C., 2006. Extensions of the multi criteria analysis with pairwise comparison under a fuzzy environment. International Journal of Approximate Reasoning 43,268-285.

Kuo, Y.F., Chen, P. C., 2010. Constructing performance appraisal indicators for mobility of the service industries using Fuzzy Delphi Method. Expert Systems with Applications 38(2).

Lankoski, L., 2000. Determinants of Environmental Profit. Helsinki University of Technology, Helsinki.

Lawrie, G., Cobbold, I., 2004. Third-generation balanced card: Evaluation of an effective strategic control tool. International Journal of Productivity and Performance Management 53(7), 611-623.

Lee, A.H.I., Chen, W.C., Chang, C.J., 2008. A fuzzy AHP and BSC approach for evaluating performance of IT department in the manufacturing industry in Taiwan. Expert System with Applications 34, 96-107.

Lee, Amy H.I., Chang, Hsing-Jen, Lin, Chun-Yu, 2009. An evaluation model of buyer-supplier relationships in high-tech industry-The case of an electronic components manufacturer in Taiwan. Computers and Industrial Engineering 57, 1417-1430.

Lee, Ki-Hoon, 2012. Carbon accounting for supply chain management in the automobile industry. Journal of Cleaner Production 36, 83-93.

Leung, L.C., Lam, K.C., Cao, D., 2006. Implementing the balanced scorecard using the analytic hierarchy process and the analytic network process. Journal of the Operational Research Society 57(6), 682-691.

Leung, L.C., Cao, D., 2000. On consistency and ranking of alternatives in fuzzy AHP. European Journal of Operational Research 124(1), 102-113.

Li, Y.N., Tan, K.C., Xie, M., 2002. Measuring web-based service quality. Total Quality Management 13(5), 685-700.

Lin, M.C., Wang, C.C., Chen, M.S., Chang, C.A., 2008. Using AHP and TOPSIS approaches in customer-driven product design process. Computers in Industry, 59, 17-31.

Lin, X., Zhang, Y., 2009. Bank ownership reform and bank performance in China. Journal of Banking and Finance 33(1), 20-29.

Lozano, R., 2012. Towards better embedding sustainability into companies' systems: an analysis of voluntary corporate initiatives. Journal of Cleaner Production, 25, 14-26.

Lozano, R., Carpenter, A., Huisingh, D., 2014. A review of 'theories of the firm'and their contributions to Corporate Sustainability. Journal of Cleaner Production. (In press).

Manley, J.B., Anatas, P.T., Cue Jr., B.W., 2008. Frontiers in Green Chemistry: meeting the grand challenges for sustainability in RandD and manufacturing. Journal of Cleaner Production $16,743-750$.

Martenson, R., 1985. Consumer choice criteria in retail bank selection. International Journal of Bank Marketing 3(2), 64-75.

Martinsons, M., Davison, R., Tse, D., 1999. The balanced scorecard: A foundation for the strategic management of information systems. Decision Support Systems 25, 71-88.

McDonald, L.M., Hung Lai, C., 2011. Impact of corporate social responsibility initiatives on Taiwanese banking customers. International Journal of Bank Marketing, 29(1), 50-63.

Meyer, D.W., Markiewicz, M.K., 1997. Developing a balanced scorecard at Wachovia corporation. Bank Accounting and Finance 11(1), 13-19.

Möller, A., Schaltegger, S., 2005. The sustainability balanced scorecard as a framework for ecoefficiency analysis. Journal of Industrial Ecology 9(4), 73-83. 
This paper is a preprint of the paper that will appear in the Business Strategy and the Environment journal (2017)

Molyneux, P., Altunbas, Y., Gardener, E., 1997. Efficiency in European Banking. New York: John Wiley and Sons.

Murray, J.D., White, R.W., 1983. Economies of scale and economies of scope in multiproduct financial institutions: A study of British Columbia Credit Unions. The Journal of Finance 38(3), 887-902.

Neely, A., Bourne, M., Kennerley, M., 2000. Performance measurement system design: developing and testing a process-based approach. International Journal of Operations \& Production Management 20(10), 1119-1145.

Nist, T.J., 1996. For best service, match needs to bank's delivery process. Corporate Cash flow 17(7), 30-32.

Önüt, S., Kara, S.S., Isik, E., 2009. Long term supplier selection using a combined fuzzy MCDM approach: A case study for a telecommunication company. Expert Systems with Applications 36(2), 3887-3895.

Palmer, K.W., Oates, W.E., Portney, P.R., 1995. Tightening environmental standards-the benefit-cost or the no-cost paradigm. Journal of Economic Perspectives 9(4), 119-132.

Perez, A., Garcia de los Salmones, M.M., Rodriguez del Bosque, I., 2013. The effect of corporate association on consumer behavior. European Journal of Marketing, 47, 218-238.

Pinero, C.J., 2002. The balanced card: An incremental approach model to health care management. Journal of Health Care Finance 28(4), 69-80.

Poolthong, Y., Mandhachitara, R., 2009. Customer expectations of CSR, perceived service quality and brand effect in Thai retail banking. International Journal of Bank Marketing, 27(6), 408-427.

Porter, M., van der Linde, C., 1995. Green and competitive: Ending the stalemate. Harvard Business Review September-October, 120-134.

Raut, R.D., Bhasin, H.V., Kamble, S.S., Sayan, B., 2011. An integrated Fuzzy- AHP- LP (FAHLP) approach for supplier selection and purchasing decisions. International Journal of Services and Operations Management 10(4), 400-425.

Ravi, V., Kurniawan, H., Thai, P.N.K., Kumar, P.R., 2008. Soft Computing system for Bank Performance Prediction. Applied Soft Computing 8, 305-315.

Reserve Bank of India, 2006 Annual report. www.rbi.gov.in, last accessed on May $13^{\text {th }} 2013$,

Saaty, T.L., 1980. The analytic hierarchy process. New York: McGraw-Hill.

Sallyanne Decker, O., 2004. Corporate social responsibility and structural change in financial services. Managerial Auditing Journal, 19(6), 712-728.

Seçme, N.Y., Bayrakdaroglu, A., Kahraman, C., 2009. Fuzzy performance evaluation in Turkish Banking Sector using Analytic Hierarchy Process and TOPSIS. Expert Systems with Applications 36, 11699-11709.

Seuring, S., Müller, M., 2008. From a literature review to a conceptual framework for sustainable supply chain management, Journal of Cleaner Production 16(15), 1699-1710.

Sharma, M.K., Bhagwat, R., 2007. An integrated BSC-AHP approach for supply chain management evaluation. Measuring Business Excellence 11(3), 57 - 68.

Shen, L., Olfat, L., Govindan, K., Khodaverdi, R., Diabat, A., 2012. A fuzzy multi criteria approach for evaluating green supplier's performance in green supply chain with linguistic preferences. Resources, Conservation and Recycling, 74, 170-179.

Szekely, F., Knirsch, M., 2005. Responsible leadership and corporate social responsibility: metrics for sustainable performance. European Management Journal 23 (6), 628-647.

Tseng, M.L., Lin, Y.H., and Chiu, A.S.F., 2009. FAHP based study of cleaner production implementation in PCB manufacturing firms, Taiwan. Journal of Cleaner Production 17(14), 1249-1256.

Tseng M.L., 2011. Green supply chain management with linguistic preferences and incomplete information. Applied Soft Computing, Vol.11 (8), 4894-4903. 
Tseng, M.L., Tan, R.R., and Siriban-Manalang, A.B., 2013a. Sustainable consumption and production for Asia: sustainability through green design and practice. Journal of Cleaner Production, Vol. 40, 1-5.

Tseng, M.L., 2013b. Modeling sustainable production indicators with linguistic preferences. Journal of cleaner production, Vol. 40, 46-56.

Wagner, M., Schaltegger, S., 2004. The effect of corporate environmental strategy choice and environmental performance on competitiveness and economic performance: an empirical study of EU manufacturing. European Management Journal, 22 (5), 557-572.

Wang, T.C., Chang, T. H., 2007. Application of TOPSIS in evaluating initial training aircraft under a fuzzy environment. Expert Systems with Applications 33(4), 870-880.

Wong-On-Wing, B., Guo, L., Li, W., Yang, D., 2007. Reducing conflict in balanced scorecard evaluations. Accounting, Organizations and Society 32, 363-377.

World Business Council for Sustainable Development (WBCSD) and World Resources Institute (WRI), 2009. The Greenhouse Gas Protocol Initiative: Scope 3 Accounting and Reporting Standard, Review Draft Switzerland, Geneva.

Wu, H.Y., Tzeng, G., Chen, Y., 2009. A fuzzy MCDM approach for evaluating banking performance based on Balanced Scorecard. Expert Systems with Applications 36, 1013510147.

Wu, Hung-Yi, 2012. Constructing a strategy map for banking institutions with key performance indicators of the balanced scorecard. Evaluation and Program Planning 35, 303-320.

Yongvanich, K., Guthrie, J., 2006. An extended performance reporting framework for social and environmental accounting. Business Strategy and the Environment 15, 309-321.

Zhang, H.C., 2004. Foreword special section on the IEEE international symposium on electronics and the environment. IEEE Transactions on Electronics Packaging Manufacturing 27(1), 1. 